\title{
УДК 65-02
}

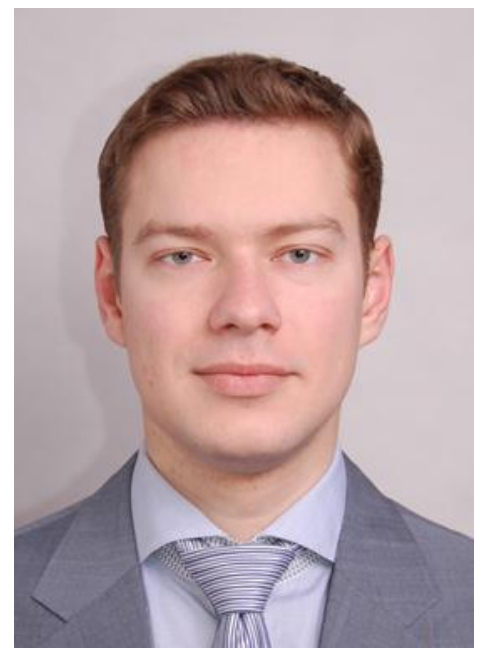

\author{
ЯНIН \\ Володимир Андрійович \\ аспірант Державного університету \\ інфраструктури та технологій \\ МОН України \\ volodymyrianin@gmail.com \\ (м. Київ)
}

\section{Л.С. ЛЕБЕДЯНСЬКИЙ: ОСТАННІ РОКИ ЖИТТЯ ТА ТВОРЧА СПАДЩИНА ВИДАТНОГО КОНСТРУКТОРА ЛОКОМОТИВІВ}

У статті зроблена спроба дослідити життя конструктора Л.С. Лебедянського, а саме його останні роки. Причиною для иього послугувала фактична відсутність інформації щодо даної тематики, а наявна, лише частково висвітлює біографічні дані через призму творчості конструктора. Тому метою даного дослідження $є$ пошук та систематизація інформаиіі стосовно фактів з життя Л.С. Лебедянського та його творчої спадщини.

У статті описуються останні роки роботи конструктора на Коломенському заводі та причини його звільнення та виходу на пенсію. Крім того, розглядаються останні роки життя Л.С. Лебедянського та його творча спадщина, а саме найбільш значущі проекти конструктора. Також, у статті розповідається про найбільш відомих послідовників та учнів Л.С. Лебедянського.

За допомогою фактів, отриманих з періодичних видань міста Коломни та джерел з Коломенського заводу, з'ясована інформація щзодо останніх років життя конструктора Л.С. Лебедянського. Визначено, що Л.С. Лебедянський значно вплинув на подальший розвиток локомотивобудування в иілому та на окремі його напрямки, а також на виховання та навчання нового покоління локомотивобудівельників.

Ключові слова: Л.С. Лебедянський, конструктор, локомотив, газотурбовоз, Коломенський завод, спадщина.

\section{L.S. LEBEDYANSKYI: THE LAST YEARS OF LIFE}

\section{AND LEGACY OF REMARKABLE LOCOMOTIVE DESIGNER}

In the article the attempts to discover the life of the designer L.S. Lebedyanskyi are made. While the former major designer of Kolomenskyi plant is widely known 
due to his projects, such as steam locomotive «L» or diesel locomotive TEP60, the facts from his life are staying mostly unknown. So, the major goal of this article is to find information related more to the life of L.S. Lebedyanskyi focusing on the last years of his work on Kolomenskyi plant, his life after retirement and his legacy.

The article reviews shortly the decisions of L.S. Lebedyanskyi from the 1955 up to 1963. However, the main focus is made on the importance of projects for L.S. Lebedyanskyi and explanation why he was so persistent while trying to save the gas turbine locomotive development program. In addition, the article observes the possible reasons for major designer's retirement. Talking about L.S. Lebedyanskyi's legacy, the article reviews his greatest projects. Among the projects that are mentioned in the article, there are the following: steam locomotive «L», steam locomotive P36, diesel locomotive TEP60, and gas turbine locomotive G1-01. Furthermore, the article also focuses on the most known followers of the former major designer of Kolomenskyi plant.

So, using the periodical of Kolomna town and resources provided via Kolomenskyi plant the information about the life and legacy of L.S. Lebedyanskyi is gathered. It becomes obvious, that the former major designer of Kolomenskyi plant influenced on the development of the locomotive industry in general and some of its branches in particular. In addition, he has made a great impact on the future generation of locomotive designers.

Key words: L.S. Lebedyanskyi, designer, locomotive, gas turbine locomotive, Kolomenskyi plant, legacy.

\section{Л.С. ЛЕБЕДЯНСКИЙ: ПОСЛЕДНИЕ ГОДЫ ЖИЗНИ И ТВОРЧЕСКОЕ НАСЛЕДИЕ ВЕЛИКОГО КОНСТРУКТОРА ЛОКОМОТИВОВ}

B статье сделана попьтка исследовать жизнь конструктора Л.С. Лебедянского, а именно его последние годы. Причиной этому послужило фактическое отсутствие информации данной тематики, а известные биографические факты подаются лишь через призму творчества конструктора. Поэтому целью этого исследования является поиск и систематизачия информации касательно фактов из жизни Л.С. Лебедянского и его творческого наследия.

В статье описываются последние годы работь конструктора на Коломенском заводе, причины его увольнения и выхода на пенсию. Кроме этого, рассматриваются последние годы жизни Л.С. Лебедянского и его творческое наследие, а именно наиболее значимые проекты конструктора. Так же, в статье рассказывается о наиболее известных последователях и учениках Л.С. Лебедянского.

С помощью фактов, полученных при помощи периодических изданий города Коломна и источников с Коломенского завода, была выяснена информация о последних годах жизни конструктора Л.С. Лебедянского. Определено, что Л.С. Лебедянский в значительной степени повлиял на дальнейшее развитие локомотивостроения в целом $u$ на отдельные его 
направления в частности, а также на воспитание и обучение нового поколения локомотивостроителей.

Ключевые слова: Л.С.Лебедянский, конструктор, локомотив, газотурбовоз, Коломенский завод, наследие.

За своє життя (1898-1968) конструктор Л.С. Лебедянський неодноразово доводив свій професіоналізм та здатність працювати над найрізноманітнішими проектами. Спочатку Лев Сергійович був визнаний як видатний конструктор паровозів. Згодом він довів, що має право називатися фахівцем широкого профілю, в короткий термін освоївши на Коломенському заводі виготовлення тепловозів. Крім того, паралельно з роботою над випуском тепловозів, Л.С. Лебедянський також працював над амбітним проектом по створенню локомотивів з газотурбінними двигунами. Слід зазначити, що Лев Сергійович став піонером цього напрямку у колишньому Радянському Союзі.

Але на превеликий жаль, не зважаючи на значні здобутки у локомотивобудуванні, у наші дні відомо досить мало фактів з життя видатного конструктора. Більшість інформації про Льва Сергійовича подається через призму його роботи над тим чи іншим проектом у збірниках, присвячених опису локомотивів колишнього Радянського Союзу. Наприклад, книга «Локомотивы отечественных железных дорог 1845-1955» та «Локомотивы отечественных железных дорог 1956-1975» за авторства В.А. Ракова, або у статтях, присвячених певному з локомотивів, наприклад, статті у журналах «Наука и техника» та «Техника молодёжи». Тому метою даного дослідження $\epsilon$ систематизація та збір інформації про життя Льва Сергійовича, пошук та опис ще невідомих або маловідомих фактів про видатного конструктора. Основним напрямком цієї статті, що є ідейним продовженням попередніх досліджень біографії Л.С. Лебедянського, буде заключний період життя конструктора, його останні роки та його творча спадщина.

В цілому останні роки роботи були надзвичайно продуктивними для, на той час головного конструктора Коломенського заводу, Л.С. Лебедянського. Не враховуючи цілого ряду технічних та ескізних проектів, у період з 1955 року і 
до 1960 року, Лев Сергійович встиг спроектувати п’ять нових локомотивів: три тепловози і два газотурбовози [1, с. 169]. 31960 р. і до 1963 р. конструктор був цілковито поглинутим роботою над газотурбовозами. Проходили випробування газотурбовозу Г1-01 та проводилось проектування більш потужних локомотивів з газотурбінними двигунами. Та на жаль, не усім ідеям Льва Сергійовича судилося втілитися у реальність.

У червні 1963 р. директор Коломенського заводу повідомив головного конструктора Л.С. Лебедянського про згортання програми щодо виготовлення газотурбовозів та розробки нових зразків даних локомотивів [1, с.170]. Існує декілька версій щодо причини таких змін у напрямках майбутніх розробок Коломенського заводу під керівництвом конструктора Л.С. Лебедянського. Найбільш вірогідною причиною можна вважати перепони зі сторони Міністерства важкого i транспортного машинобудування колишнього Радянського Союзу. У країні активно розвивалися дизелефікація та електрифікація тогочасної залізниці, в чому і було зацікавлене Міністерство. Крім того, існував цілий ряд спеціалістів, що тим чи іншим способом лобіювали саме ці напрямки розвитку залізниці колишнього Радянського Союзу. 3 іншого боку, існує припущення, що причиною згортання програми по розробці нових газотурбовозів стала суперечка Л.С. Лебедянського з Головою Президії Верховної Ради колишнього Радянського Союзу М.С. Хрущовим щодо ККД газотурбовозу Г1-01. Відбулась дана суперечка на виставці, присвяченій Всесоюзній нараді залізничників у квітні 1963 року в присутності робітників промислового відділу ЦК ВКП(б). Хоча, якою б не була причина, факт, що вже за місяць, у червні того ж року, головний конструктор Л.С. Лебедянський дізнався про жахливу для нього новину.

Важко навіть уявити, наскільки сильним було потрясіння Льва Сергійовича під час розмови 3 директором Коломенського заводу. Саме Л.С. Лебедянський організував проектування та виробництво газотурбовозів. Під його керівництвом створювалися нові цехи та конструкторське бюро, проводилась перекваліфікація персоналу. Без перебільшення, Лев Сергійович 
поклав усі свої сили на розвиток газотурбовозобудування, що стало справою усього його життя. У палкій суперечці з директором Коломенського заводу у 6річного Льва Сергійовича стався серцевий напад $\mathrm{i}$ його було негайно госпіталізовано.

Вже за декілька днів Лев Сергійович прийшов до тями. Він не став затримуватися у лікарні і майже одразу повернувся на завод. Л.С. Лебедянський поновив переговори 3 директором щодо продовження робіт над газотурбовозами. На жаль, переговори не мали успіху, а цех для збірки газотурбовозів, який побудували зусиллями головного конструктора, передали дизелістам. Варто зазначити, що колектив, створений Львом Сергійовичем, не розвалився. Раз в неділю вони проводили наради з головним конструктором щодо здобутків та планів на майбутнє. Врешті-решт, через посилення конфронтації з директором заводу В.М. П'ятовим головний конструктор Лев Сергійович Лебедянський у 1963 р. був вимушений піти на пенсію.

Л.С. Лебедянському та В.М. П'ятову довелося зустрітися знову в актовій залі Коломенського заводу під час святкування 100 - річчя підприємства 5-го жовтня 1963 р. В той день Лев Сергійович отримав свою останню нагороду, другий орден Трудового Червоного Знамені [1, с. 171].

Щодо нагород Л.С. Лебедянського, керівництво колишнього Радянського Союзу високо оцінювало здобутки видатного конструктора, що також підтверджує високе значення робіт Льва Сергійовича. За своє життя Л.С. Лебедянський став лауреатом Сталінської премії, двічі отримував почесне звання «Отличник паровозостроения», отримав орден Леніна, двічі орден Трудового Красного Знамені, медаль «За доблестный труд в Великой Отечественной войне», медаль «За оборону Москвы», знак «Передовой конструктор советского машиностроения», знак «Почетный железнодорожник» та звання «Генерал - директор II ранга» [1, с. 164; с. 165; 5$]$.

I хоча Лев Сергійович пішов на пенсію, силами його послідовників було завершено один з останніх проектів головного конструктора. У 1964 році побудували два пасажирських газотурбовози ГП1. Ці локомотиви стали 
останніми газотурбовозами, які створили на теренах колишнього Радянського Союзу. Газотурбовози базувалися на ходовій частині та кузові тепловозу ТЕП60, також проект Л.С. Лебедянського. На локомотивах ГП1 встановили турбогенераторну установку потужністю 3500 кінські сили, що, на жаль, не використовувалась на повну потужність через те, що потужність тяглових електродвигунів не перевищувала 3000 кінські сили. Через рік газотурбовози ГП1 своїм ходом направилися в депо Льгов, де проходили випробування на магістральній службі.

3 моменту виходу на пенсію Лев Сергійович буквально втратив сенс свого життя. Працюючи на КМЗ Л.С. Лебедянський кожного дня, часто навіть на вихідні, впродовж 42 років йшов на завод, який став йому рідним. Тепер Лев Сергійович не мав куди йти та не знаходив собі місця. Колишній головний конструктор КМЗ дуже переживав. До усіх розчарувань додався ще й інсульт, що трапився зі Львом Сергійовичем та паралізував усю його праву частину тіла. Та варто зауважити, що мужність не покинула Л.С. Лебедянського, який вперто намагався навчитися писати лівою рукою, але, на превеликий жаль, сили поступово покидали видатного конструктора.

30 січня 1968 р. Лев Сергійович Лебедянський помер. Його урочисто поховали усім колективом Коломенського заводу. Похоронна процесія зібралась на площі перед Палацом культури підприємства. Під час поховання Льва Сергійовича відбувся траурний мітинг на Старому кладовищі (тогочасне міське кладовище № 1). Першому слово було надано Дмитру Васильовичу Львову, колишньому заступнику Л.С. Лебедянського [3]. У той день промовили багато теплих слів в пам'ять головного конструктора Коломенського заводу, а в конструкторський відділ підприємства ще довгий час поступали телеграми та листи зі співчуттями від людей та колективів, які тим чи іншим шляхом були пов'язані та знайомі зі Львом Сергійовичем.

Усю скорботу, ставлення та повагу до конструктора Л.С. Лебедянського дуже вправно описала Коломенська поетеса М. Мещерякова у 1998 р. (100- 
річчя від дня народження Льва Сергійовича) за допомогою наступних рядків [3]:

\author{
Славных дел скупая проза \\ Или память о корнях, \\ И страна без паровоза, \\ Что телега без коня. \\ От подножья до вершины \\ Сто дорог пришлось открыть, \\ Что стальную мощь машины \\ Жизнью одухотворить. \\ Из угля, огня и стали \\ Чудо сотворить сумел. \\ Лебединой песней стали \\ Паровозы с буквой «Л». \\ Генерал-директор тяги \\ До сих пор ему в набат \\ Те колеса, как бродяги, \\ Магистральный пульс стучат.
}

За своє життя Л.С. Лебедянський приймав безпосередню участь у проектуванні, або являвся головним конструктором наступних проектів: паровози серії $\mathrm{C}^{\mathrm{y}}, \mathrm{C}^{\mathrm{yM}}$, ФД, ЙС, 2-3-2К, 5П, 9П, ЕР, Л, ОР23, П34, П36, П38, тендер - конденсатор до паровозу серії СО-19, бустер, теплопаровоз ТП-1, тепловози серій ТЕ50, ТЕП60, ТГП50, та газотурбовози Г1 та ГП1 [1, с.153; 5]. Навіть сухий перелік проектів не залишає сумнівів у геніальності та різноплановості конструктора Л.С. Лебедянського. Він був спеціалістом широкого профілю, роботи якого залишили слід в історії. Деякі з проектів Льва Сергійовича стали більше ніж просто успішними і тому на цих проектах хотілося б зупинитися докладніше у контексті творчої спадщини Л.С. Лебедянського.

Перш за все, варто згадати паровоз П32, згодом Л. I хоча в наші дні цей паровоз можна побачити лише у вигляді пам'ятників, наприклад: місто Коломна 31989 р. та місто Вологда з 2007 р., даний локомотив мав неабияке значення у творчості та становленні Льва Сергійовича як успішного конструктора. Крім того, паровоз П «Победа» (до 1947 р.), з заводським позначенням П32, став безпрецедентним випадком, коли локомотив назвали на 
честь конструктора Л.С. Лебедянського. В ті часи, у колишньому Радянському Союзі це був перший такий випадок, а враховуючи безпартійність Льва Сергійовича, перейменування паровозу на його честь у 1947 р. і зовсім виглядає як фантастика. До того ж, Л.С. Лебедянський, разом 3 ведучими конструкторами Г.А. Жиліним, В.К. Чистовим, В.Д. Уткіним, Д.В. Львовим та В.Д. Д'яковим, отримав Сталінську премію за створення паровозу Л. І не дивно. Паровоз типу 1-5-0 серії Л став наймасовішим вантажним паровозом колишнього Радянського Союзу, завдяки якому країна, що потребувала паровозів, набагато легше змогла відновитися після війни. Причиною було те, що вантажообіг проходив по залізниці. I саме паровоз серії Л став локомотивом, який мали змогу використовувати по усій території країни, не зважаючи на поганий стан залізничного полотна. За період випуску, з 1945 р. до 1950 р., побудовано 4199 паровозів серії на трьох заводах: Коломенському, Брянському та Ворошиловградському [6, с. 308].

Ще одним надважливим проектом Льва Сергійовича став магістральний пасажирський паровоз П36. Його доля схожа $з$ паровозом серії Л. А саме, як паровоз серії Л у свій час використовувався на усіх проміжках залізниці колишнього Радянського Союзу для вантажних перевезень, так і магістральний пасажирський паровоз П36 замінив інші локомотиви на усіх головних залізницях країни. Отже, локомотиви П36 обслуговували як правило головні лінії 3 дальніми поїздами на Жовтневій, Білоруській, Куйбишевській, Калінінській, Сталінській, Красноярській та Північній залізницях. Варто зазначити, що паровоз Пз6 значно перевершував тогочасні аналоги по потужності. Використання цього локомотиву дало змогу не лише збільшити швидкість, а й підвищити загальну масу поїздів. Для прикладу, проходження проміжку Москва - Ленінград після заміни локомотиву на паровоз П36 зменшилось на 1 годину та 45 хвилин. Лише масовий перехід на тепловозну та електровозну тягу став причиною відмови від використання паровозів П36. Хоча паровози П36 почали виводити $з$ експлуатації у 1956 р., даний тип локомотивів продовжували використовували аж до 1974 р. [6, с. 322]. 
Паровоз П36, спроектований Л.С. Лебедянським, без перебільшення ввійшов в історію. Це був останній пасажирський паровоз колишнього Радянського Союзу. На згадку про цей дивовижний локомотив у багатьох сучасних містах встановлено пам'ятники. Москва (РФ), Санкт - Петербург (РФ), Брест (Білорусія), Мукран (Германія), Улан - Батор (Монголія) - це лише короткий перелік міст, де можна побачити паровоз П36 у якості пам'ятки. Також, варто зазначити, що велика кількість паровозів й досі знаходиться у робочому стані.

Наступний проект Л.С. Лебедянського, що вартий уваги, зважаючи на значення для залізниці того часу та навіть для сучасності, є тепловоз ТЕП60. Тепловоз ТЕП60, що випускався на Коломенському заводі став найпершим пасажирським тепловозом колишнього Радянського Союзу. Саме цей локомотив, на відміну від попередніх проектів, що по своїй суті були лише модернізованими вантажними тепловозами, спеціально спроектували для пасажирської служби. Тепловоз ТЕП60 отримав широке розповсюдження на головних магістралях країни. За час серійного випуску локомотиву з 1961 p. i до 1985 р. побудовано 1241 одиниць даної машини. Станом на 1 січня 1976 р. на залізниці колишнього Радянського Союзу знаходилося 710 тепловозів серій ТЕП60. Дані локомотиви обслуговували Жовтневу (181 од.), Білоруську (86 од.), Прибалтійську (61 од.), Придніпровську (67 од.), Московську (65 од.), Південно-Східну (39 од.), Південну (16 од.), Свердловську (92 од.), Приволжську (45 од.) та Західно-Сибірську (58 од.) залізниці [7, с. 174]. Тепловози ТЕП60 стали не лише основними пасажирськими локомотивами на усіх неелектрифікованих проміжках залізниці, а й у цілому ряді випадків обслуговували приміські лінії.

I хоча локомотив 3 початку 1980-х років почав поступатися більш сучасним зразкам тепловозів та електровозів, тепловоз ТЕП60 можна вважати одним 3 найважливіших проектів Л.С. Лебедянського у розумінні творчої спадщини конструктора. Даний тепловоз ще багато років використовувався на залізниці навіть після того, як Льва Сергійовича не стало. Залізниці колишнього 
Радянського Союзу, України, Росії, Естонії, Литви, Латвії обслуговувалися тепловозом ТЕП60 до 2000-х років. Щодо Білорусії, то станом на 2012 р. ця країна й досі експлуатувала локомотив, спроектований конструктором Л.С. Лебедянським.

Але, мабуть, найбільш значущим та амбітним проектом Л.С. Лебедянського стала його робота над локомотивами 3 газотурбінними двигунами, газотурбовозами. Створення опитного зразка газотурбовозу Г1-01 повністю лягло на плечі Льва Сергійовича. А пасажирські газотурбовози ГП10001 та ГП1-0002 виготовили вже послідовники конструктора. I хоча газотурбовози не знайшли розповсюдження на теренах колишнього Радянського Союзу, внесок Льва Сергійовича у розвиток газотурбовозобудування неоціненний. Саме натхненні його роботою спеціалісти по газотурбовозобудуванню організували ініціативну групу та продовжили проектування ГТД. Серед їхніх проектів машини Г2Р, ГІП1, ГІП1Р, ГЕ4, які на жаль не вдалося побудувати. Згодом, саме ця група спроектувала ГТД з потужностями 12 та 21 тисяча кінські сили і ККД до 50\% [1, с. 172]. 3 часом побудували декілька газотурбовозів 3 новими ГТД, один 3 яких мав конструкційну швидкість рівну 200 км/год [1, с. 172]. Розробки у напрямку газотурбовозобудування продовжувались. Вже на теренах сучасної РФ побудували локомотив з ГТД потужністю 8300 кВ, або 11300 кінські сили [2; 9]. Вагомий внесок у його створення внесли спеціалісти ВАТ «ВНИКТИ» 3 міста Коломна, певне що натхненні роботами Л.С. Лебедянського, як піонера даного напрямку локомотивобудування. Локомотив працює на зрідженому газі i за рахунок відносної дешевизни палива, його виготовлення окупиться впродовж 9 років [8]. Отже, Л.С. Лебедянський не дарма поклав свої останні сили на розвиток доволі перспективних у майбутньому локомотивів.

Крім колосальних здобутків Льва Сергійовича на ниві локомотивобудування, не варто забувати й інший аспект його творчої спадщини. А саме, внесок конструктора у виховання нового покоління інженерів залізничників. Так під керівництвом Л.С. Лебедянського та водночас 
навчаючись у видатного конструктора, зростали молоді спеціалісти, що згодом стали непересічними фахівцями у своїй сфері. Серед них були Г.А. Жилін, колишній заступник Льва Сергійовича, а згодом i головний конструктор Коломенського заводу. Саме цей конструктор відігравав важливу роль у розробці багатьох проектів Л.С. Лебедянського. Ще один 3 учнів Льва Сергійовича, Юрій Васильович Хлебніков, очолив Коломенський філіал Московської політехніки (1968-1972), а згодом також зайняв високу посаду головного конструктора Коломенського заводу [4]. Крім того, Лев Сергійович був наставником цілого ряду конструкторів Муромського та Брянського заводів. Серед колишніх учнів Льва Сергійовича неабияке місце займає й майбутній керівник тепловозного бюро Харківського паровозобудівного заводу, Олександр Олександрович Кінарський - автор цілого ряду проектів серійних магістральних тепловозів.

Отже, Л.С. Лебедянський був, без перебільшення, геніальним конструктором локомотивів різних видів. Лев Сергійович визнаний спеціаліст паровозобудівельник та тепловозобудівельник, а також піонер та ідейний лідер напрямку газотурбовозобудування. Головний конструктор Коломенського заводу та лауреат цілої низки премій і нагород, спеціаліст, що вартий глибокого та детального вивчення не тільки через призму виконаних робіт та реалізованих проектів, а й зі сторони особистого життя. Вважаю, що подальші дослідження є більш ніж доцільними і цілком можливими за рахунок пошуку нащадків конструктора на теренах РФ, співпраці 3 Коломенським заводом, музеєм Коломенського заводу та Центральною Коломенською бібліотекою.

\section{Список використаних джерел}

1. Боченкова В.В., Бычкова Е. В. История и перспективы развития Коломенского завода. Коломна, 2011. 232 с.

2. Жиганова Е. Наш паровоз вперёд летит. Угол зрения. 2007. № 18 (337).

3. Запевалов Ю. К 115-летию Коломзавода. Bопрос-Omвет. 2013. № 83 (1168).

4. Костюченко Т., Кузнецова С., Ильина А. Коломенский завод и Коломенский институт: более полувека сотрудничества. Политех. 2013. № 1 (88). С. 3 . 
5. Кузовкин А. Впервые в истории локомотивостроения. Угол зрения. 2008. № 3 (374).

6. Раков В. А. Локомотивы отечественных железных дорог (18451955 гг.). Москва : Транспорт, 1995. 564 с.

7. Раков В. А. Локомотивы отечественных железных дорог (19561975 гг.). Москва : Транспорт, 1999. 443 с.

8. Щербакова Е. Поддать газу : газотурбовоз. Популярная механика. 2010. № 10 .

9. История // АО «Научно-исследовательский и конструкторскотехнологический институт подвижного состава» (АО «ВНИКТИ»), 2013. URL : http://www.vnikti-kolomna.ru/about/history/ (дата звернення : 12.09.2017).

\section{References}

1. Bochenkova, V. V. and Bychkova, E.V. (2011). Istoryia $i$ perspektivy razvityia Kolomenskoho zavoda. [History and perspectives of the development of Kolomenskyi plant]. Kolomna, 232. [in Russian].

2. Zhihanova E. (2007). Nash parovoz vpered letit. [Our steam locomotive is flying forward]. Uhol zreniia [Vision angle]. 18 (337). [in Russian].

3. Zapevalov, Iu. (2013). K 115-letiiu Kolomzavoda [Dedicated to the $115^{\text {th }}$ anniversary of Kolomenskyi plant].Vopros Otvet [Question Answer]. 89 (1168). [in Russian].

4. Kostiuchenko, T., Kuznetsova, S. and Ilina, A. (2013). Kolomenskyi zavod $i$ Kolomenskyi instytut: bolee poluveka sotrudnichestva. [Kolomenskyi plant and Kolomenskyi institute: more than half of a century of collaboration]. Politekh [Polytech]. 1 (88), 2-3. [in Russian].

5. Kuzovkin, A. (2008). Vpervye v istorii lokomotivostroeniia. [The first time in a history of the locomotives' production]. Uhol zreniia [Vision angle]. 3 (374). [in Russian].

6. Rakov, V.A. (1995). Lokomotyvy otechestvennykh zheleznykh doroh (18451955). [Locomotives of native railways (1845-1955)]. Moskva : Transport, 564. [in Russian].

7. Rakov, V.A. (1999). Lokomotyvy otechestvennykh zheleznykh doroh (19561975). [Locomotives of native railways (1956-1975)]. Moskva: Transport, 443. [in Russian].

8. Shcherbakova, E. (2010). Poddat hazu : hazoturbovoz. [Turn up the gas: gas turbine locomotive]. Populiarnaia mekhanika [Popular mechanics]. 10. [in Russian].

9. $A O ~ « V N I K T I »$. [JSC «VNIKTI»]. (2013). Istoriia. [History]. Retrieved September 27, 2017, from: http://www.vnikti-kolomna.ru/about/history/ [in Russian].

\section{Рецензент:}

Коцур А.П., д.і.н., професор

Надійила до редакції 27.09.2017 p. 